\title{
Próxima publicación de Rituales festivos de Andalucía en el portal web del IAPH
}

El Instituto Andaluz del Patrimonio Histórico a través de su portal web publicará próximamente el producto de documentación y difusión Rituales festivos de Andalucía, cuyo objetivo principal es mostrar una parte de la gran diversidad y riqueza de estas manifestaciones a lo largo del territorio andaluz desde una perspectiva antropológica. El propósito es documentar la mayoría de los rituales festivos atendiendo también a su inmediata difusión.

Dentro de los elementos que conforman el patrimonio inmaterial de Andalucía, tienen un lugar protagonista los rituales festivos, entendidos como un fenómeno cultural en el que se unen diferentes valores patrimoniales. La fiesta define al grupo social que la protagoniza y a través de ella se expresan sentimientos individuales y colectivos que se reproducen y reactivan cada año en el momento festivo. Es una manifestación viva y dinámica con una gran potencialidad de cambio y adaptación a las transformaciones sociales.

La ampliación de nuestro conocimiento sobre las fiestas y su diversidad en Andalucía contribuye a eliminar ciertos tópicos e imágenes mix- tificadas y homogeneizadas de los comportamientos festivos-ceremoniales andaluces. Y lo que es más importante, ayuda a dar a conocer la fiesta como fenómeno social y cultural, y no como una mera manifestación folclórica; como una manifestación cultural dinámica, y no como una práctica anacrónica y conservadora.

Este espacio del portal web del IAPH dedicado a documentar las fiestas andaluzas pretende mostrar los diferentes elementos y los más significativos que se dan durante el desarrollo de las mismas, y puede servir para comprender la riqueza de estos momentos simbólicos: espacios para el ritual, indumentaria, modelos organizativos, modos de

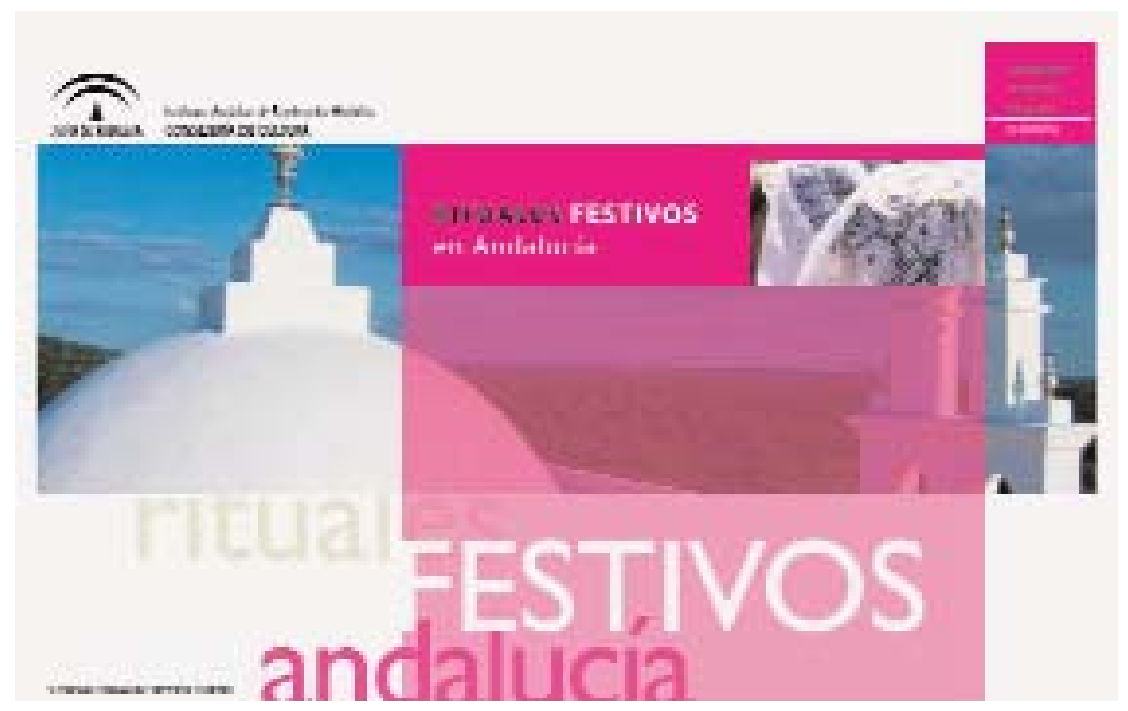




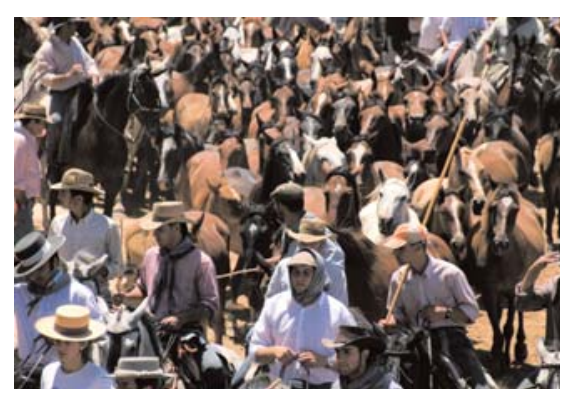

(1) Saca de las yeguas. Almonte (Huelva) / Foto: AnicETo

Delgado Méndez, IAPH

expresión significativos (danzas rituales, música...), comensalismos, etcétera.

Las fiestas son reflejo del devenir histórico andaluz y de su vitalidad actual, y constituyen una de nuestras principales señas identitarias, considerando su diversidad como un referente clave de la riqueza cultural de Andalucía.

Gema Carrera Díaz

Centro de Documentación del IAPH

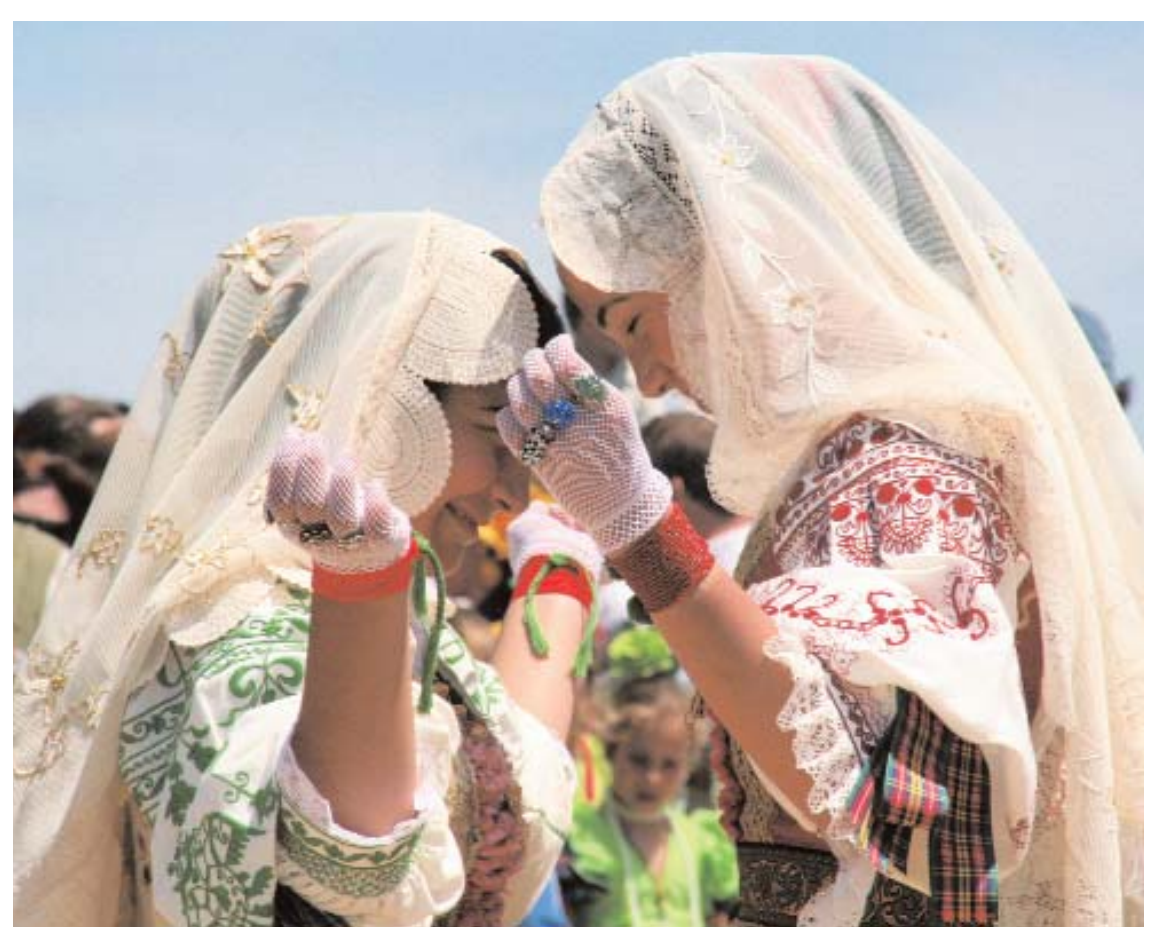

(1) Romería de San Benito. Cerro de Andévalo (Huelva) / Foto: Aniceto Delgado MÉndez, IAPH

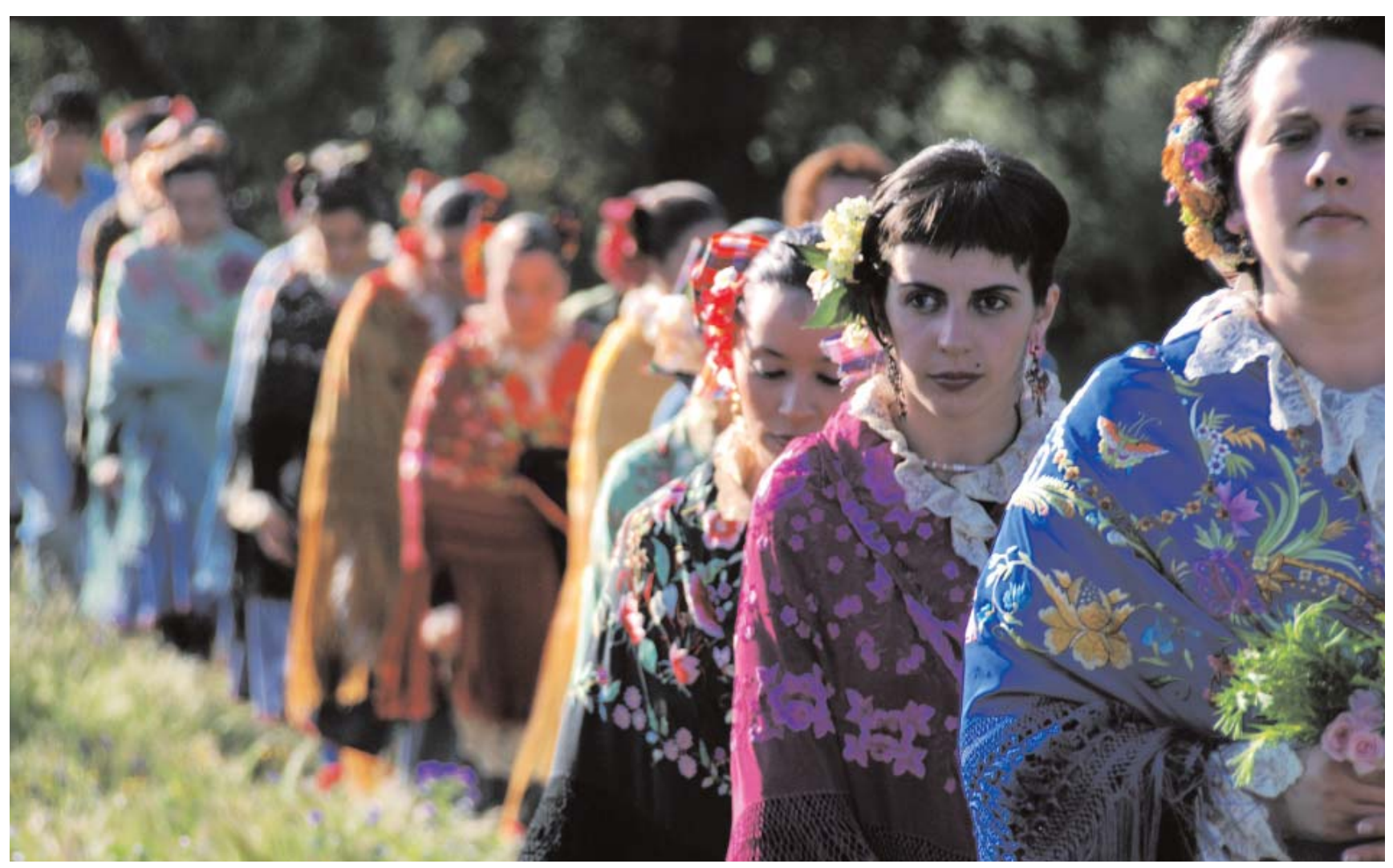

(1) Cruces de mayo. Almonaster la Real (Huelva) / Foto: Aniceto Delgado MÉndez, IAPH 